\title{
Article
}

\section{Rethinking Revisionist Social Democracy: The Case of the Manifesto Group and Labour's 1970s 'Third Way'}

Meredith, Stephen Clive

Available at http://clok.uclan.ac.uk/10942/

Meredith, Stephen Clive ORCID: 0000-0003-2382-1015 (2014) Rethinking Revisionist Social Democracy: The Case of the Manifesto Group and Labour's 1970s 'Third Way'. Labour History Review, 79 (2). pp. 201-225. ISSN 09615652

It is advisable to refer to the publisher's version if you intend to cite from the work. http://dx.doi.org/10.3828//hr.2014.10

For more information about UCLan's research in this area go to http://www.uclan.ac.uk/researchgroups/ and search for <name of research Group>.

For information about Research generally at UCLan please go to http://www.uclan.ac.uk/research/

All outputs in CLoK are protected by Intellectual Property Rights law, including Copyright law. Copyright, IPR and Moral Rights for the works on this site are retained by the individual authors and/or other copyright owners. Terms and conditions for use of this material are defined in the policies page. 


\title{
Rethinking Revisionist Social Democracy: The Case of the Manifesto Group and Labour's 1970s 'Third Way'
}

\author{
Stephen Meredith \\ University of Central Lancashire
}

The Manifesto Group of centre-right Labour MPs was established in December 1974 to combat the growing organizational strength and success of the left-wing Tribune Group in elections to Parliamentary Labour Party (PLP) office, and to buttress the 1974 Labour government against the general advance of the left within the party. It was also an attempt to respond to the emerging incoherence of the personnel and programme of revisionist social democracy and to attempt to organize the centre-right of the PLP under a single banner. In policy terms, it concerned itself inevitably with analysis of economic and industrial policy, both as a critique of the perceived limitations of Labour's attachment to conventional tools of Keynesian social democratic political economy as it crumbled in the $1970 \mathrm{~s}$ and as a'moderate' social democratic'third way' response to the emerging alternatives of the Labour left's Alternative Economic Strategy (AES) and the neo-liberalism of the New Right. Much of the meaning and impact of Manifesto Group ideas and proposals were lost in the context and clamour of economic crisis and polarized political divisions of the time. With recent claims of adherence to ideas and politics that claim to chart a 'third way' course through the mire of discrete and outmoded ideologies, emerging themes, ideas, and proposals of the Manifesto Group retrospectively possess greater resonance for analysis of the subsequent development of social democracy and social democratic political economy and emergence of 'New' Labour. The article argues that Blair's Labour Party was less a simple compact of internal and external political influences than the legatee of the interrupted and circuitous trajectory of post-revisionist social democracy from deferred Manifesto Group themes through the (Owenite) SDP, Labour's own Policy Review after the 1987 election defeat, and indirectly to 'New' Labour.

KEYWORDS: Labour Party, 1970s factionalism, Manifesto Group, economic policy, social democratic revisionism, New Labour 


\section{Introduction}

In debates concerning the familiar question of the ideological and political character and trajectory of 'New' Labour, much has been written of its revisionist social democratic antecedents as an antidote to the more immediate 'accommodation of Thatcherism' thesis of left-leaning commentators, or the 'year zero' rhetoric of leading Labour modernisers. ' 'New' Labour's initially influential 'Third Way' approach to the application of ideas and policies has also been the subject of some scrutiny of its relative novelty and associations. ${ }^{2}$ However, lost amongst the debris of so-called 'Old' Labour's difficulties and battles of the 1970s, the external and internal difficulties that beset the 1974-9 Labour government, a line of revisionist social democratic continuity between 'Old' and 'New' Labours has been neglected. Little has been written of some of the striking parallels between the ideas, remedies, and prescriptions of the Manifesto Group of centre-right Labour MPs, set up initially in 1974 to counteract the advance and success of left-wing groups in the party organization, ${ }^{3}$ and 'New' Labour's concept of 'Third Way' politics. For Blair, Giddens, and company, the 'Third Way' approach was not merely an attempt to 'split the difference' between right and left but to move 'decisively beyond an Old Left preoccupied by state control, high taxation and producer interests, and a New Right treating public investment, and often the very notions of 'society' and collective endeavour, as evils to be undone'. It advocated broadly the belief that it is possible to combine a largely free market economy with social justice, to promote a strong sense of community and stake holding while extending rather than restricting the liberty of the individual and wider opportunities for all. ${ }^{4}$ It is a contention of this article that 'New' Labour's chosen ideological framework did not so much represent the 'new type of politics' and 'new synthesis' of ideas claimed by the party's

1 See Steven Fielding, The Labour Party: Continuity and Change in the Making of 'New' Labour (Manchester, 2002); Tudor Jones, Remaking the Labour Party: From Gaitskell to Blair (London, 1996); Philip Larkin, 'New Labour and old revisionism', Renewal, 8 (2000), 42-9.

2 See Stephen Driver and Luke Martell, New Labour: Politics After Thatcherism (Cambridge, 1998); Sarah Hale, Will Leggett, and Luke Martell (eds), The 'Third Way' and Beyond: Criticisms, Futures and Alternatives (Manchester, 2004); Martin Powell (ed.), New Labour, New Welfare State? The 'Third Way' in British Social Policy (Bristol, 1999).

3 British Library of Political and Economic Science (hereafter BLPES), London, Neville Sandelson Papers, 6/1, Memo, n.d.; Labour History Archive and Study Centre (hereafter LHA), Manchester, Labour Party Manifesto Group Papers, LP/MANIF/15, Giles Radice, 'Note on the Manifesto Group's future', 14 January 1981; Financial Times, 9 March 1977.

4 See Tony Blair, The Third Way: New Politics for the New Century (London, 1998); Anthony Giddens, The Third Way: The Renewal of Social Democracy (Cambridge, 1998); Peter Mandelson and Roger Liddle, The Blair Revolution: Can New Labour Deliver? (London, 1996). 
leading modernisers, ${ }^{5}$ as the contemporary mainstream expression by a newly dominant political project of disrupted and displaced post-revisionist social democratic themes previously pursued by a relatively obscure and embattled centre-right Labour faction of the 1970s. The very little that has been written of the Manifesto Group has largely focused on its narrow instrumental operation as an internal organizational faction to combat the left in the Labour Party and presented as largely ineffective and transitory its contribution to wider debates and developments of social democracy. ${ }^{6}$ The group's own records lie largely untouched in the Labour History Museum and Study Centre of the People's History Museum in Manchester and in a section of the little-known right-wing Labour MP and Social Democratic Party (SDP) convert Neville Sandelson's papers in the British Library of Political and Economic Science at the London School of Economics.

In its attempt to expand its initial narrow tactical party goals and develop a broader ideological strategy and programme for Labour and social democracy that would both underpin the future of a Labour government and promote a moderate socialist approach and agenda 'firmly committed to the democratic socialist values of personal freedom and social equality', the Manifesto Group claimed to offer a modernizing 'middle way' or 'third possible course' between the emerging extremes of left and right. ${ }^{7}$ Following initial analysis of the issues and problems of the prevailing economic situation by leading members, including John Horam and David Marquand, ${ }^{8}$ the first and most extensive public statement of group principles and policy was eventually published in March 1977 to reasonable press coverage. It presented the broad scope of Manifesto Group philosophy and approach to the kind of 'radical and constructive change' that it believed was required, and modernizing sentiments concerning the need for change in the 'backward-looking national psychology and backward-looking institutions'. Prepared by a sub-committee of Manifesto Group 'intellectuals' of a clearly revisionist social democratic temperament, composed of Horam and Marquand, John Mackintosh, Bryan Magee, Giles Radice, and John Roper, and excepting the prevailing idiom

5 Mandelson and Liddle, Blair Revolution, 17.

6 See Radhika Desai, Intellectuals and Socialism: 'Social Democrats' and the Labour Party (London, 1994), 170-2; Dianne Hayter, Fightback! Labour's Traditional Right in the 1970s and 1980s (Manchester, 2005), 49-75.

7 LHA, LP/MANIF/18, Manifesto Group, What We Must Do: A Democratic Socialist Approach to Britain's Crisis, March 1977; LP/MANIF/20, Manifesto Group, Priorities for Labour: A Manifesto Group Statement, March 1979, 1-2; Guardian, 9 March 1977; The Times, 30 September 1977.

8 Sandelson 6/1, David Marquand, 'Economic situation'; John Horam, 'The present situation'; John Horam, 'The economy: A report for the Manifesto Group'; Manifesto Group, 'Economic report by the Manifesto Group’ for a meeting with Denis Healey, 27 February 1975. 
of the time, the document set out an alternative and potentially less divisive 'democratic socialist' programme of economic and social change to the 'equally old-fashioned' schemes of Conservatism and Marxist socialism and to those of the new 'prophets of Left and Right'. '

This article indicates the emerging weaknesses and divisions of revisionist social democratic political economy in the context of the broader crisis of Keynesian social democracy in the 1970s, before moving on to examine an attempt from within this tradition to formulate and chart an alternative 'middle course' or 'third way' post-revisionist economic and industrial strategy. It considers the context, emergence, and nature of Manifesto Group themes, ideas, and policies, and assesses the immediate impact and longer-term significance of its proposals. It suggests a neglected 'Old' Labour link in the evolution of so-called 'New' Labour's 'Third Way' ideational framework, and, in a number of senses, the concerns of the 'Old' Labour centre-right Manifesto Group pre-empt many of the central themes and priorities of the 'new' social democratic political economy of New Labour. Utilizing the under-used resource of the Manifesto Group papers, among others, the article seeks to illuminate the story of the Manifesto Group, its origins and rationale, its central concerns and contribution to social democratic politics, and its relative success (or lack of it) and social democratic legacy. It argues that, in the context of Labour politics of the time, its message and prescriptions became lost in the combination and clamour of events, developments, and battles overtaking the Labour government and Labour Party. Retrospectively, however, we can, in much of the post-revisionist analysis, perspectives, and proposals (and even some of the personnel) of the Manifesto Group, largely overlooked at the time and since and temporarily redirected through alternative social democratic channels, identify significant parallels and continuity with 'New' Labour thought and practice.

\section{6 and all that: the 'frontiers' and crisis of revisionist social democracy and a 'post-revisionist' agenda}

Commentators have viewed the 1970s, particularly the events and developments around 1975-6, as precipitating a number of a hugely significant transitions in both Britain's post-war political history and political economy. The period witnessed the related developments of the failure and demise 
of Keynesian economic strategy, which, in turn, undermined the traditional basis of social democratic political economy, the end of the supposed post-war consensus, and the emergence of an alternative ideological approach to economic policy. After 1976, the ideological basis of political economy was transformed, with fresh emphasis on the reduction and control of inflation as opposed to the maintenance of full employment and policies of redistribution through the tools of progressive taxation and public expenditure. Signalling a deep crisis of traditional social democratic political economy, the Labour government of these years appeared to have undergone a macroeconomic conversion of significant proportions. Callaghan's (in)famous decree on the limits of traditional Keynesian mechanisms was fashioned by his son-in-law, Peter Jay. Although Callaghan stopped shy of using the second half of Jay's preferred elegy indicating the need to adopt a more entrepreneurial 'market socialist' approach, his words were taken to signal a turning point in modern British politics away from the traditional economic policies and instruments of the post-war consensus, and, for some, the death throes of Keynesian social democracy in an emerging era of so-called 'New Realism'. ${ }^{10}$

Doubts remain over the extent to which Callaghan's conference speech and contraction of Keynesianism marked an immediate or wholesale shift of post-war economic policy in the direction of neo-liberal monetarist doctrine. The post-1976 economic policy of the Labour government was little different to that pursued prior to the visit of the international financiers of the International Monetary Fund (IMF), and its macroeconomic strategy, with continued emphasis on incomes policy, remained distinct from that of the early Thatcher years. ${ }^{11}$ Nonetheless, Callaghan's rhetorical flourish, tacitly acknowledging the need to incorporate monetarist elements into the government's, and Labour's, economic strategy and sewing the first seeds of the slow transition along the 'Yellow Brick Road ... from Attlee's Little Way to Blair's Third Way', found succour in elements of Labour's centre-right increasingly unconvinced of the virtues of 'high tax-and-spend' as an 'article of faith' in the post-IMF economic environment. ${ }^{12}$ Although there was little in the way

10 Labour Party, Labour Party Annual Conference Report (LPACR) (London, 1976), 188; Andy Beckett, When the Lights Went Out: Britain in the Seventies (London, 2009), 337-9; Denis Healey, The Time of My Life (London, 1991), 443.

11 Katherine Burk and Alec Cairncross, 'Goodbye, Great Britain': The 1976 IMF Crisis (London, 1992), 228; Christopher Allsopp, 'Macroeconomic policy: Design and performance', in Michael Artis and David Cobham (eds), Labour's Economic Policies 1974-79 (Manchester, 1991), 34-6.

12 Vernon Bogdanor, 'Social Democracy', in Anthony Seldon (ed.), Blair's Britain 1997-2000 (Cambridge, 2007), 169-71; Tom Clark, The Limits of Social Democracy? Tax and Spend Under Labour, 1974-79 (London, 2001); Kenneth O. Morgan, 'James Callaghan 1976-80', in Kevin Jeffreys (ed.) Leading Labour: From Keir Hardie to Tony Blair (London, 1999), 134, 149; Kenneth 
of a new overarching economic philosophy beyond the 'minutiae of anti-inflationary policy' to replace the 'passing of Croslandism', Manifesto Group members were influential in promoting the need for a 'careful review of public expenditure and anti-inflation measures' in 'conditions of low growth' and to ensure the maintenance of basic 'freedoms in society'. It represented a 'post-ideological' pragmatic 'adjustment' to 'facts of slow economic growth' and, perhaps with the exception of the strong emphasis on incomes policy, could be distinguished from Conservative presentation by no more than a 'feeling', which more recently might be described as 'Blairite'. ${ }^{13}$

In a party that by 1974 was already an 'uneasy alliance', elements of Labour's centre-right nucleus were more receptive to the possibilities and priorities of 'new thinking' on economic policy within emerging macroeconomic constraints. ${ }^{14}$ Particularly, a developing school of thought of the post-revisionist Labour right was increasingly sensitive to the perceived failures and limitations of Anthony Crosland's previously influential revisionist analysis of the egalitarian ends of social democratic political economy based on correspondingly high levels of taxation and public expenditure. The purchase and likely success of the principles and goals of Crosland's original revisionist thesis were to a large extent dependent on optimistic expectations of economic growth, which subsequently failed to materialize.

Crosland's apparent unwillingness to revise his own social democratic revisionism in light of subsequent trends in the structural economy led a number of his former social democratic disciples to attempt to reassess and reconfigure key features and goals of social democratic political economy in the context of economic circumstances unanticipated by Crosland. ${ }^{15}$ Much of this second-wave revisionist analysis was channelled through the Manifesto Group. They appeared willing to re-evaluate the application of traditional tools and priorities of social democratic political economy and to question even revisionist social democratic perspectives of the rationale and use of taxation and public expenditure in the face of the likely breach of structural limits

O. Morgan, 'Leadership and change: Prime ministers in the post-war world - James Callaghan' Gresham College Lecture (London, 2007) (http://www.gresham.ac.uk/event.asp?Page$\mathrm{Id}=45 \&$ EventId=601: accessed 1 October 2010).

13 Clark, Limits of Social Democracy, 37; Desai, Intellectuals and Socialism, 171, 172; Manifesto Group, What We Must Do, 2-4; David Marquand, interview with the author, 16 January, 2001; John Tomlinson, interview with the author, 27 March 2001.

14 Clark, Limits of Social Democracy, 35.

15 Bodleian Library (hereafter BL), Oxford, uncatalogued papers of Lord Callaghan, 'Tony Crosland memorial lecture', 2 November 1979; David Marquand, The Progressive Dilemma: From Lloyd George to Blair (London, 1999), 170; Giles Radice, 'Revisionism revisited', Socialist Commentary, May 1974, 25-7. 
of the economy in the 1970s. In effect, they were as increasingly concerned with the limits and implications of 'tax and spend' socialism as they were with the evolving neo-liberal direction of Conservative economic policy and, if it was unclear whether they were willing to question both the traditional means and ends of revisionist social democracy, to borrow archetypal Croslandite discourse, they were certainly increasingly sensitive to the 'art of the possible' in terms of the relative emphasis afforded to the prerequisite of economic growth and ideas of equality and liberty in public policy.

\section{Organizing against the left and the road to a 'third way': origins and development of the Manifesto Group}

The growing influence of the Labour left in the party after the 1970 general election defeat, partly in response to the perceived failures of the Wilson governments, in which influential figures of the centre-right were seen as culpable, precipitated the emergence of identifiable 'moderate' factional party groupings for the first time since the Campaign for Democratic Socialism (CDS) in the early 1960, both to counter the progress of the left in the party and to pursue specific agendas in relation to economic and industrial issues and policy. The leftward shift of the party was reflected in the publication of Labour's Programme 1973, which advocated radical proposals of nationalization, economic planning, and wealth redistribution, ${ }^{16}$ and in the subsequent formation of the left-wing Campaign for Labour Party Democracy (CLPD) in 1973 to promote internal constitutional reforms designed to benefit the left in the wider organs of the party structure. ${ }^{17}$

As a statement of the left-wing institutional and policy challenge, the long-time leftwinger, Ian Mikardo, was elected to the chairmanship of the PLP in 1974, and Tony Benn's star was rising in the party as chair of the influential Home Policy Committee of Labour's National Executive Committee (NEC). Together with the perception of the onset of aggressive industrial action and potential challenge to the rule of law in response to developments such as the Heath government's Industrial Relations bill, Labour's previously dominant tradition of moderate social democracy was sensitive to the rising left-wing tide and began to warn of the dangers of a 'populist socialist' appeal to sectional and class-based politics and the need for a 'renewed emphasis

16 Labour Party, Labour's Programme 1973 (London, 1973), 13-39, 40-2.

17 Labour Party, Labour's Programme 1973, 6. 
on parliamentary democracy' in the national interest. ${ }^{18}$ With an echo of the attempts of 1950s Labour revisionism to counter the effects of 'affluence' on the party's appeal, some 'moderates' perceptively expressed concern over the ability of the increasingly disparate ideas and personnel of centre-right social democracy to return the party to a path of moderation necessary to appeal to an increasingly diverse and 'dealigned' electorate. Brian Walden, for instance, expressed the belief that 'the Right was clapped out and ideologically incoherent' and, in the adverse circumstances, 'did not know what to do'. ${ }^{19}$ The narrow election victory of October 1974 served only to conceal trends that indicated the decline of Labour's electoral support, and prefigured the invasive rise of the Labour left in the party and growing trade union militancy that included a shift to the left among a number of trade union leaderships. ${ }^{20}$ The dilemmas and conflicts of the Labour Party were to be compounded rather than moderated by election victory and experience of office. It was in the context of left-wing, trade union, and wider pressures on the economic and industrial policies of the Labour government, and the success of left-wing organization and activity in the PLP, that Labour's centre-right determined to attempt to halt their relative institutional and intellectual decline and organize more formally through the Manifesto Group.

The Manifesto Group was a group of eighty or so Labour MPs with origins largely on the centre-right of the party, as noted, established initially in December 1974 to confront the shift in the balance of election to party office leftwards, particularly the success of the left-wing Tribune Group in this respect. The election of Mikardo demonstrated the increasing organizational cohesion and effectiveness of the parliamentary Labour left and alarmed many of the traditional centre-right majority. It drew attention to the fact that, in important elections to the various offices and significant channels of the PLP, the centre-right vote was often split between two or more candidates and allowed the highly organized Tribune Group to elect their chosen candidate. In addition to the chairman of the PLP, Tribune members dominated both the Liaison Committee of the PLP, the important channel of communication between Labour backbenchers and Labour government, and the leadership of backbench subject groups. Given the inroads already made

18 John P. Mackintosh, 'Socialism or Social Democracy? The choice for the Labour Party', Political Quarterly, 43 (1972), 484; Roy Jenkins, What Matters Now (London, 1972), 21-2.

19 Quoted in Gerard Daly, 'The Crisis in the Labour Party 1974-81 and the Origins of the 1981 Schism', PhD thesis, University of London, 1992, 75; BLPES, Reginald Prentice Papers, 6/5, 'Recollections of a trade unionist'.

20 See David Butler and Dennis Kavanagh, The British General Election of February 1974 (London, 1974), 268; BLPES, Prentice 6/5, 'Recollections of a Trade Unionist', 9-10. 
in the research and policy spheres of the party, it looked increasingly possible that the future programme of a Labour government could be underscored by potential left-wing economic and anti-EEC measures. In the absence of a single leader of the Gaitskell variety who might be able to unite the centrist and revisionist social democratic right in the face of the left-wing onslaught, a number of concerned junior lieutenants, including Horam, Marquand, Radice, Roper, Cledwyn Hughes, Dickson Mabon, Neville Sandelson, and Alan Lee Williams, took it upon themselves to initiate organized representation of the Labour right in the PLP. ${ }^{21}$

Although the Manifesto Group was not the same as, or merely a formal extension of, the emerging 'Jenkinsite' tendency of the revisionist Labour right around the leadership of Roy Jenkins, some overlap of personnel and perspective between the groups favoured more formal social democratic organization in the party. ${ }^{22}$ Unlike the Jenkinsites (and the Tribune Group), however, the Manifesto Group remained an exclusively backbench organization of the PLP, which precluded the involvement of Labour's frontbench representatives, largely on the grounds that "only by being clearly independent of the Government will our voice be heard. ${ }^{23}$

Because of fear of the proliferation of the 'Prentice effect' of left-wing reprisals in constituency Labour parties (CLPs), the group refused to publish its membership list, ${ }^{24}$ but did constitute 'a formal group' in terms of organization, structure, and membership. It 'met in ... a committee room in the House of Commons and it did have officers and an agenda'. ${ }^{25}$ The Manifesto Group 'was formed to deal with a purely Parliamentary situation' and it remained a 'purely Parliamentary' organization. Initially, 'its focus on PLP elections' meant that only Labour MPs were eligible for membership, but Labour peers were then included as 'many of them showed interest in the Group and because the Group itself inevitably widened its interest to include discussion of Government policy and of democratic socialism in general'.

21 BLPES, Sandelson 6/1, note headed 'The Manifesto Group', n.d.

22 Although support for the manifesto on which Labour was elected in 1974 was as far as the Manifesto Group was prepared to go, even this would have been too far for some Jenkinsites given the relatively left-wing tone and substance of the document. For discussion of the relative distinctiveness and overlap of the Jenkinsite group, see Stephen Meredith, 'Factionalism on the parliamentary right of the British Labour Party in the 1970s: A reassessment', Contemporary British History, 21 (2007), 55-85.

23 LHA, LP/MANIF/23, John Wakefield to Paul Adamson, 3 February 1978 and 27 February 1978.

24 BLPES, Prentice 6/17, 'Recollections of a trade unionist', ch. 7; Sandelson, 'The Manifesto Group'; John Wakefield to Paul Adamson, 3 February 1978 and 27 February 1978; LP/MANIF/9, George Robertson to Manifesto Group members, January 1980; LP/MANIF/25, Dennis Canavan to Ian Wrigglesworth, 18 March 1979; Ian Wigglesworth to Dennis Canavan, 20 March 1979.

25 Marquand, interview with the author. 
The membership, which by early 1979 had reached 'about sixty backbench Labour MP[s] in addition to about fifteen Labour peers', paid an annual subscription, but, with the exception of the frontbench disqualification, there was 'no formal criteria of membership'. Original members 'got together because they shared views on relevant matters, and the Group is loose enough for the question of "suitability" not to arise'. In terms of officers, group members nominated and elected a chairman, three vice-chairman, a treasurer, and a secretary at the beginning of each parliamentary session in November. The Group also received funding from the Joseph Rowntree Social Service Trust to employ a full-time researcher/administrator. ${ }^{26}$

The organizational structure of the group was based around a weekly meeting on a Wednesday evening in the parliamentary session open to all group members. Occasional open meetings were also organized, open to all members of the PLP. Contact between officers of the group was constant and informal, and it was suggested that 'the Group, like most Parliamentary bodies, works informally rather than through rigid procedures'. Apart from the Rowntree Trust grant, the main sources of income came from membership subscriptions and small amounts from the sale of its periodic policy statements. With the exception of these occasional pamphlets, the group did not release regular publications and had "no "internal documentation" that it would be worthwhile $\ldots$ reading'. ${ }^{27}$

Although the Manifesto Group aimed to offer reinforcement to the beleaguered Labour government, unlike its right-wing factional predecessor, the Gaitskellite Campaign for Democratic Socialism (CDS), its relationship with the parliamentary leadership was never better than ambiguous. The new leader, Callaghan, was opposed to the idea of intra-party groupings of all types and unwilling to endorse even factions of the centre-right leadership-loyalist variety, such as the Manifesto Group. After his election to the party leadership in April 1976, Callaghan declared that would 'not be willing to accept a situation in which minority groups in the Parliamentary Labour Party manoeuvre in order to foist their views on the party as a whole'. ${ }^{28}$ Although it had been the nature of the centre-right to look to the elected leader for patronage and

26 John Wakefield to Paul Adamson, 27 February 1978; LP/MANIF/25, John Wakefield to Roger Poole, 23 January 1979.

27 John Wakefield to Paul Adamson, 27 February 1978; John Wakefield to Roger Poole, 23 January 1979; Ian Wrigglesworth, Tribune, 30 December 1977; LP/MANIF/4, Ian Wrigglesworth, 'Notes on Manifesto Group meeting', 11 January 1978; LP/MANIF/7, George Robertson to Ron Hayward, March 1980.

28 The Times, 22 April 1976; BL, uncatalogued Callaghan papers, speeches and speech notes, 79-80, speech to the All Wales Rally, Brecon, 5 July 1980. 
leadership, Callaghan was 'cautious about endorsing a campaign conducted in his name'. He had long been averse to any divisive factional activity and 'groups running around in the party flogging their minority wares'. For Callaghan, it was unity that mattered most and he wanted to 'command the soft [left and] centre as well as the right'. ${ }^{29}$

Others, such as David Owen, Denis Healey, Bill Rodgers, and Roy Hattersley, were more sympathetic to the group's aims and ideals, but as ministers none could be seen to openly endorse the group and generally it was 'provided with no protective shield' by the parliamentary leadership, whether it was the "left-wing Harold Wilson or, perhaps surprisingly, the more right-wing Callaghan, who saw his role as a balancing one, rather than as favouring either side'. ${ }^{30}$

Equally, a further irony and difficulty for the group was the nature of the manifesto from which it drew its name. A declared aim of the group in its 'independently' supportive role of the Labour government and party leadership was to help uphold the party's 1974 election manifesto, even if a majority of its membership was ambivalent or opposed to much of its substance, not least the 'sweeping nationalization proposals and ... revolutionary sounding promise of a "fundamental and irreversible shift in the balance of power and wealth in favour of working people and their families". ${ }^{31}$ The point was that the manifesto was the limit of how far they were prepared to go to implement socialism, and in the context of increasing economic and industrial difficulties the Manifesto Group developed its limited initial objectives to support and implement the party manifesto and act as an organizational counterweight to the Tribune Group and update the ideological parameters of 'democratic socialism'.

Initially, the Manifesto Group campaign to overturn Tribune Group victories in elections to important posts of the PLP met with a good degree of success. In the PLP elections held after the October 1974 general election, Cledwyn Hughes was elected to the chair as a single unifying candidate of the Labour centre-right. There was also a significant improvement in the election of its preferred candidates to the important Liaison Committee of the PLP, and it was claimed that after 'the formation of the Manifesto Group its candidates were elected to all the backbench seats on the Liaison Committee and

29 LHA, LP MANIF/1, William Rodgers to Alec McGivan, 15 November 1979; Kenneth Morgan, interview with the author, 17 October 1997.

30 William Rodgers to Alec McGivan, 15 November 1979; Hayter, Fightback, 50, 56-7.

31 Ivor Crewe and Anthony King, SDP: The Birth, Life and Death of the Social Democratic Party (Oxford, 1997), 24. 
they have continued to have a clean sweep'. ${ }^{32}$ Buoyed by such successes, the group broadened its rationale and objectives beyond the mere organization of the right-wing slate in PLP elections. Elected officer posts within the group were established, and a full-time researcher was appointed to collate material for the purpose of publishing Manifesto Group policy statements 'intended to spread its ideas about democratic socialism much more widely'. ${ }^{33}$ The broader purpose was to extend the role and scope of the Manifesto Group 'to include discussion of Government policy and of democratic socialism in general', and to offer a contribution to the battle of ideas in the party, particularly in the critical areas of economic and industrial policy. Consequently, the group undertook to publish a number of statements and papers 'on matters of current interest' and as a 'contribution to debate in the party'. ${ }^{34}$

\section{The principles of democratic socialism and social democratic 'renewal': revisionist social democracy and a 'third way' in the 1970s}

In addition to the initial party strategic aim and the objective to defend the manifesto platform on which the Labour government had been elected to grapple with the mounting economic challenge, the broader purpose of the Manifesto Group was to prompt a post-revisionist 'modernising' ambition to both uphold the traditional principles of democratic socialism and re-evaluate social democratic philosophy and policy in shifting economic, social, and political circumstances. ${ }^{35}$ The wider aims and objectives of the group beyond intra-party organization included a supportive motion to defend the policies presented in the Labour manifesto and help to sustain the Labour government to overcome the current 'acute economic difficulties'. ${ }^{36}$

Given the relatively left-wing nature of the party's manifesto, there was some irony in both the group's choice of name and intention to uphold the document on which the Labour government had been elected in 1974. On

32 John Wakefield to Paul Adamson, 27 February 1978.

33 BLPES, Sandelson 6/1, Neville Sandelson to Manifesto Group members, n.d.; John Wakefield to Paul Adamson, 27 February 1978.

34 John Wakefield to Paul Adamson, 27 February 1978; John Wakefield to Roger Poole, 23 January 1979; George Robertson to Ron Hayward, March 1980; Manifesto Group, What We Must Do; Manifesto Group, Priorities for Labour; LP/MANIF/3, Manifesto Group, The Future of Counter-Inflation Policy, January 1979.

35 See Tony Blair, Let Us Face the Future - The 1945 Anniversary Lecture (London, 1995), 1, 3-5, 9, $10-13,14$.

36 LHA, LP/MANIF/15, memo headed 'The committee proposes', n.d.; LP/MANIF/4, 'Notes and (supporting) statement of Manifesto Group meeting', 15 June 1977; George Robertson to Ron Hayward, March 1980; Sandelson, 'The Manifesto Group'. 
the one hand, it was representative of the growing defensiveness of moderate party opinion in expressing its loyalty to the moderate party leadership and locating itself broadly within the Labour Party tradition. On the other, it represented a reluctant acceptance of, rather than explicit support for, Labour's manifesto. Although this was as far as most members of the Manifesto Group were prepared to go, it offered something of social democracy to defend. ${ }^{37}$ However, the rationale and role of the Manifesto Group was more than that of a mere 'rubber stamp' for the government. It was also both an attempt to uphold and reassert the 'democratic socialist principles' of the party against what were perceived to be the inherent dangers to economic and political order of the resurgent 'far left' and to provide a social democratic revisionist 'modernising' forum 'to relate democratic socialist philosophy to the needs of the present age' and attempt to intercept the parallel challenge of the new 'Tory Right'. ${ }^{38}$

The group's initial statement of philosophy and policy, What We Must Do: A Democratic Socialist Approach to Britain's Crisis (1977), demonstrated the twin aims of its wider prospectus to offer discussion of both current economic and political themes and the development and direction of social democracy more generally. In the immediate and likely future economic context, the statement consistently stressed 'the importance of wealth creation, restraining public expenditure and ... holding down wage claims to within the Chancellor's limits'. The document restated the group's faith in limited planning and the mixed economy but, in accord with an emerging 'liberal' social democratic political economy of the Labour right increasingly sensitive to the tax and spend limits at 'the frontiers of social democracy', repudiated increased public expenditure and simple redistribution of wealth. ${ }^{39}$ Instead, it emphasized the importance of wealth creation as a centrepiece of social democratic political economy and as a stimulus of economic growth: 'Progressive taxation and increased public expenditure have been pursued with too little regard for overall cost and too optimistic a view of the likely benefits.' Wealth creation

37 Financial Times, 9 March 1977; John Horam, interview with the author, 16 February 2001.

38 Manifesto Group, 'The committee proposes'; George Robertson to Ron Hayward, March 1980; John Wakefield to Paul Adamson, 3 February 1978 and 27 February 1978; John Wakefield to Roger Poole, 23 January 1979; LHA, LP/MANIF/23, John Wakefield to Patrick Seyd, 13 March 1978; LP/MANIF/25, John Wakefield to Patrick McSharry, 18 August 1978; John Wakefield to R.F. Atkins, 17 January 1979; BLPES, Sandelson 6/1, Manifesto Group, 'Phase four: where to go from here'; Financial Times, 9 March 1977.

39 See Stephen Meredith, 'Labour Party revisionism and public expenditure: Divisions of Social Democratic political economy in the 1970s', Labour History Review, 70 (2005), 254, 259, 262; Shirley Williams, interview with the author, 25 June 2002; William Rodgers, interview with the author, 18 February 2001. 
'must be given a new priority that it had never previously achieved in socialist thinking'. ${ }^{40}$ A revisionist social democratic perspective between the poles of left and right, willing to loosen ties to traditional policies and mechanisms and adapt to new limits and the need for reform, suggested that only an updated application of the principles of moderate democratic socialism could deliver 'the radical, sweeping and integrated economic and social changes necessary to reverse the process of Britain's economic decline', low growth and rate of inflation, their unanticipated social consequences and the accompanying 'institutional rigidities' that lay behind them, and still preserve fundamental concepts of individual freedom and social equality. ${ }^{41}$ Principal themes of ideological and programmatic renewal were accompanied by an appeal for renewal of Britain's institutional and social structure and attitudes as a driver of economic recovery, echoing Harold Wilson's earlier focus on a 'new Britain' devoid of 'restrictive' attitudes and practices and 'New' Labour's later 'new Labour new Britain' embodiment of wider institutional and national renewal.

In effect, it represented a 'modernising' agenda - even a 'middle way' or 'a third possible course' - within a broadly social democratic framework. ${ }^{42}$ Given the significant younger revisionist (and Jenkinsite) component of Manifesto Group membership, it was in no small way an attempt to update Crosland's seminal social democratic revisionism for the prevailing circumstances of unanticipated economic conditions of low economic growth and high inflation (which Crosland himself appeared unable or unwilling to do). In the adverse conditions of low economic growth, increasing unemployment, and high inflation, it was Crosland's, and Labour's, seemingly unreconstructed reliance on traditional forms of Keynesian demand management and the high priority afforded to public spending and high and progressive levels of taxation in pursuit of redistributive policies to achieve the aim of greater economic and social equality, that provided a focus of the Manifesto Group's social democratic revisionism.

While members of the Manifesto Group were very largely in favour of high levels of public expenditure as the basis of 'a prosperous and civilised society' in conditions of stronger economic growth, it also warned of the potentially damaging consequences of high levels of taxation and public expenditure 'against a background of slow or stagnant growth'. Developing the emerging Jenkinsite theme of the potential dangers to freedoms of increased public

40 Manifesto Group, What We Must Do, 12; The Times, 30 September 1977.

41 Manifesto Group, What We Must Do, 5-6, 7-9, 10-12, 13; Manifesto Group, 'Economic report', 27 February 1975; Financial Times, 9 March 1977; The Times, 30 September 1977.

42 See Daily Telegraph, 9 March 1977. 
spending as a proportion of GDP, the group's initial statement took the analysis a stage further to question some of the wider principles of public expenditure. In particular, it questioned the unplanned and wasteful aspects of increases in public expenditure, and even the reliability of its redistributive effects, and warned of the danger of a 'taxpayers backlash ... against the whole idea of the Welfare State'. ${ }^{43}$

Manifesto Group statements did not argue for a retreat from the considered use of public expenditure and role of the state, but suggested that

it is because we believe in socially valuable public expenditure that we think there should be greater scrutiny of it. Indiscriminate cuts in public spending made in hasty response to economic crisis often have harmful consequences for our social fabric [but] ... much greater attention should be paid to preventing wasteful public spending, to looking at ways of getting greater cost benefit from spending and ending public programmes which change has rendered unnecessary. ${ }^{44}$

A hint of the language and approach of early 'New' Labour and Gordon Brown becomes apparent in Manifesto Group perspectives of the new priorities and uses of economic policy. With the optimistic forecasts and central tools of social democratic political economy increasingly called into question in the economic conditions of the 1970s, the group emphasized a more permanent rather than contingent focus on inflation and monetary control as the new way to stability and growth and more focused use of public and social expenditure. These themes proposed in a Labour context broadly correspond to the representations of 'New' Labour on the new 'rules' of economic engagement and useful deployment of the proceeds of economic growth and limits of untrammelled public expenditure. In his speech to a memorial meeting for Tony Crosland in February 1997, Brown outlined his views of the 'changing context of equality', in which the principle of a 'rise in public spending does not necessarily equate with meeting the public interest' in the same way that in 1956 'increased public ownership was not synonymous with the public interest', equality, and social justice. ${ }^{45}$

Although his observations remained largely undeveloped for the "hard times' of the 1970s, Crosland himself noted the uncertainties of the benefits of

43 Manifesto Group, What We Must Do, 12, 22-4; also see Lewis Minkin, The Contentious Alliance: Trade Unions and the Labour Party (Edinburgh, 1991), 209, 231; Philip Whitehead, The Writing on the Wall: Britain in the Seventies (London, 1985), 346.

44 LHA, LP/MANIF/3, Manifesto Group, 'Keep on course: A statement of economic policy', 27 October 1976.

45 Gordon Brown, 'Equality - then and now', in Dick Leonard (ed.), Crosland and New Labour (Basingstoke, 1999), 35-48. 
spending and that social democrats were faced with the uncomfortable notion that 'a shift from private spending to public spending does not necessarily increase equality.' According to Brown, 'the record since 1979' had shown that 'increased spending does not necessarily increase social justice,' that 'you can tax, spend, borrow ... and [still] fail', and central Manifesto Group themes had begun to address, unravel, and advertise some of these uncomfortable developments and embryonic revisions of social democratic political economy. ${ }^{46}$ The largely unheralded Manifesto Group proposals for a stable economy for growth without severe inflationary and unemployment pressures, through the pursuit and maintenance of a 'firm, anti-inflationary monetary policy' encompassing a clearer framework of pay and wage bargaining, reflected a strategy to charter a 'third' possible course of revisionist social democracy between the similarly 'chaotic free-for-all' options of new right and left, emphasizing 'modernising' sentiments that present policies needed to be (re) considered by government, party, and movement, up-dated and refashioned for a purpose for the future. ${ }^{47}$

Equally, it is possible to detect an emerging interest in the 'supply-side' economy in Manifesto Group proposals rather than the conventional focus on demand of social democratic political economy. Though the 'obvious response to signs of sluggishness in the economy is to call for a stimulus to demand', while there is both 'greatly under-used capacity, particularly of human skill' and 'unsatisfied human want', it 'must be our ambition to build a growing economy which develops and employs that supply in providing for that demand'. ${ }^{48}$ A further latent 'New' Labour theme of the Manifesto Group reflected a growing awareness of the dilemmas of the 'trade union question' and shifting attitudes to the 'position of special power' enjoyed by trade unions in the limits to which they believed the government should accede to the demands of narrow trade union interests of 'irresponsible wage bargaining' in a difficult national economic climate, and the need for social democracy and the Labour Party to explicitly adopt and present a 'national' rather than sectional perspective and appeal. ${ }^{49}$ Some members of the group

46 Manifesto Group, 'Keep on course'; National Library of Scotland (hereafter NLS), Edinburgh, John P. Mackintosh Papers, 323/139, Manifesto Group, 'Economic policy', 13 March 1978; LHA, LP/MANIF/3, Manifesto Group, 'Statement on the budget', 11 April 1978; also see Brown, 'Equality', 37-9; Anthony Crosland, Social Democracy in Europe (London, 1975); Anthony Crosland, 'Equality in hard times', Socialist Commentary, October 1976, 3.

47 Manifesto Group, 'The future of counter-inflation policy', LHA, LP/MANIF/3, Manifesto Group, 'Statement on the TUC General Council statement, "A better way”, 1 February 1979.

48 Manifesto Group, 'Economic policy'.

49 Manifesto Group, 'Statement on the TUC General Council statement'; LHA, LP/MANIF/3, Manifesto Group, Statement, 15 November 1978; Minkin, Contentious Alliance, 209-10. 
were even more explicit in their belief that a future social democratic party (of whatever form), freed from the institutional constraints and conservative limitations of the trade unions, "would be free to press for what it saw as the national interest' and could be 'far more radical on many issues'. ${ }^{50}$

Additional attempts were made to both emphasize the Manifesto Group's 'third way' approach and augment its own radical Labour/social democratic credentials by taking up the wider battle of ideas with the publication of a clear anti-Conservative statement in June 1978 attacking new Conservative ideas and policies. The Wrong Approach: An Exposure of Conservative Policies was essentially an attempt to provide the Manifesto Group with an offensive anti-Thatcherite as well as a defensive anti-left position, and to emphasize the alternative appeal of an updated moderate social democracy willing to accept a reassessment of the precepts of social democratic industrial relations and political economy in conditions of low growth, but not the perceived vagaries and inequalities induced by the New Right's laissez-faire principles of the 'Invisible Hand of the market mechanism' in industrial and economic policy. Again, in an attempt to charter a responsive centre-right ideological position in the Labour Party in the post-IMF environment in which 'Keynesianism had been defeated and old-style Croslandism-in-one-country was in disarray,' the Manifesto Group pursued a 'third way' course something akin to a 'kind of marriage between Keynesianism and Monetarism'.${ }^{51}$ It is perhaps no coincidence, with the left largely routed, that the group faded in the party by the mid-1980s as the 'Kinnockite' Policy Review process and the course of Labour's social democratic modernization gradually addressed, and thus removed, its raison d'être.

As they approached the more immediate juncture of the 1979 election contest with Thatcherism and the foreseeable future, the 'priorities for Labour' and a modernized social democracy were to plot a moderate, responsive and realistic social democratic course between the perceived excesses of a 'tried [and] failed' and likely disruptive 'laissez-faire Tory ideology' and the outdated and unrealistic proposals of the Labour left's AES, involving massive and unaffordable reflation, 'greatly increased import controls, nationalisation and compulsory planning agreements'. In the context of government-led economic success centred around the principle and 'only realistic policy' of 'cooperation and partnership, not just between a Labour Government and the

50 John P. Mackintosh, 'Socialism or social democracy?', 483-4; also see John P. Mackintosh, 'The case for a realignment of the left', The Times, 22 July 1977.

51 Manifesto Group, 'The future of counter-inflation policy'; Manifesto Group, 'Phase four'; Manifesto Group, 'Priorities for Labour'; Hayter, Fightback, 56. 
trade unions, but between unions and industrialists, and between both and government', the group advocated a 'permanent incomes policy' as a weapon to fight inflation and a more sophisticated approach to the debate on public spending beyond the mere quantitative arguments of right and left. The Conservative argument that public spending inherently presents a burden on freedoms is unacceptable because 'many less wealthy people depend on public services for the limited freedoms they do enjoy.' The aim to increase public spending to enhance wider freedoms and opportunities remains, but 'the money can only be found out of real resources, through taxes and borrowing. It cannot be conjured out of thin air, and that's why we dispute the left's view' as 'they simply beg the question of economic growth and close their eyes to the inflationary consequences of their policies. ${ }^{52}$

Other modernizing themes of the Manifesto Group's vision reflected some of the later 'prudence for a purpose' rhetoric of Gordon Brown, indicating that public spending for the pursuit of 'Social justice and better provision for those in need and who depend on it' remained central to social democracy, but with the strong proviso that it had 'to be paid for'. '[E]ffective and efficient public spending' and 'efficient public use of resources' within a vibrant growing economy would have to underpin grand social democratic values. ${ }^{53}$ These further proposals included reform of the Common Agricultural Policy (CAP) and review of Britain's budgetary commitment to the EEC, both in the economic context of the argument 'for the efficient public use of resources' and the political context of fostering 'popular support' for Britain to remain in the Community and developing a more stable pro-European position; encouragement of new enterprise, tax reform, and greater appreciation of the 'importance of incentives and differentials', which would be 'vital if the British economy is to grow more strongly'; and more industrial democracy as a means of fostering 'greater cooperation between all sides of industry', involving 'new responsibilities on trade unionists' and 'internal trade union reform', in pursuit of 'more productive, efficient and less disrupted industry'. The Manifesto Group's final rallying call immediately prior to the 1979 general election was not too dissimilar to some of the introductory and explanatory language of 'New' Labour. It suggested that if a (Labour) government applied 'economic and industrial policies that work', Britain could become

a more equal society, a less divided society, a society in which people gain more control over their lives, more choice over how they spend their time

52 Manifesto Group, 'The future of counter-inflation policy'; Manifesto Group, 'Priorities for Labour'. 53 Gordon Brown, Parliamentary Debates (Commons), 308, 17 March 1998, 111; Manifesto Group, 'Priorities for Labour'. 
and their money ... We have addressed ourselves ... to ... how to make the British industrial economy stronger, and how to release the imaginative and creative forces in British society that have so long been underused. On these practical, workable policies ... Labour can create the opportunity of a fuller life for everyone. ${ }^{54}$

The limited overall impact of Manifesto Group proposals at the time reflected both the wider fraught context and polarized battle of ideas and the continued advance of the left in the policy-making apparatus of the party, particularly after 1979. It also reflected to some extent the consequences for the Manifesto Group's coherence and compass of the inability of its 'paralysingly diverse' centre-right membership to adopt a unified approach to wider key themes such as the European issue and position on the Common Market. ${ }^{55}$ If the Manifesto Group outlook failed to ignite 'a new philosophical and political revival within the Labour Party' advocated by social democrats in the revisionist tradition, such as David Owen, and failed to offer a wider prospectus and engage explicitly with emerging preoccupations of liberal social democracy around related themes of 'decentralisation and democracy' both within and without the Labour movement, it was an attempt to elevate perspectives beyond 'our own internal constitutional and organisational problems' and offer a 'laudable modernising' objective to reassess the focus, priorities, and distribution of moderate revisionist social democratic political economy in the wake of 'new and unanticipated' conditions. In this respect, they emphasized the destructive tendencies of free collective bargaining and the appeal of a permanent but flexible incomes policy and pay norm, a new priority and 'more firmness and consistency' in economic policy on anti-inflationary measures and tighter monetary policy, and a reassessment of the possibilities of public expenditure in conditions of low growth in a way that would prevent public spending as a share of GDP reaching 'levels which would imperil "freedom" in society'. As part of this process and the wider 'modernising' agenda, the group called for a broader shift to overcome 'a profound resistance to change' in the 'backward-looking' national psyche and national institutions (à la 'new Labour new Britain'). ${ }^{56}$

54 Manifesto Group, 'The future of counter-inflation policy'; Manifesto Group, 'Priorities for Labour'; Hayter, Fightback, 57.

55 Desai, Intellectuals and Socialism, 171-2; LHA, LP/MANIF/25, Ian Wrigglesworth to J.P. Smith, 18 March 1977; John Wakefield to Francois Xavier Camenon, 17 January 1979, Manifesto.

56 LHA, LP/MANIF/24, extract from speech delivered by David Owen to the Northfield Constituency Labour Party dinner, Birmingham, 29 February 1980; Manifesto Group, 'Phase four'; Manifesto Group, 'Priorities for Labour'; Desai, Intellectuals and Socialism, 172. 


\section{From New Labour to 'New' Labour}

the Manifesto Group of centre-Right Labour MPs published a pamphlet ... it hopes will ... bring up to date the principles of Democratic Socialism ... Unlike most Labour documents, the pamphlet ... puts the emphasis on wealth creation rather than the distribution of wealth ... wealth creation must be given a priority which it had never previously had in Socialist thinking ... Parts of the new pamphlet read as if they had been drafted in Conservative Central Office. 'The principal object of economic and industrial policy is to produce an atmosphere in which innovation thrives, risks are worth taking, profitability is satisfactory, and efficiency is a habit. ${ }^{57}$

The Manifesto Group should be seen perhaps as an important (and neglected) indirect, rather than direct, influence on the emergence of 'New' Labour, given its ultimately very temporary existence and largely strategic internal organizational role in the party up to 1983 and subsequent reproduction of much of its platform by the seemingly more interesting secessionist SDP, ${ }^{58}$ and given the more general difficulty of linking the influence and relationship of sets of ideas across time, context, and personnel.

However, there is a sense in which it is possible to chart the more indirect trajectory of the essence of Manifesto Group proposals to their 'New' Labour destination through the complex and circuitous route and schisms of social democracy in the 1980s and 1990s - from core Manifesto Group themes and ideas as a post-revisionist social democratic pressure group of the Labour right in the 1970s, through the formation of a new alternative social democratic vehicle involving some of the group's members and sympathizers and David Owen's repositioning of the SDP after the 1983 election, and through the Owenite SDP to Labour's belated attempts at 'renewal' and Policy Review after 1987 and the modernisers of 'New' Labour in the mid-1990s. In this respect, Owen's concept of the 'social market' offers a useful route map of the trajectory and migration of post-revisionist themes and ideas through the various twists and turns of British social democracy from the mid-1970s to the mid-1990s.

If the Manifesto Group was attempting to achieve a new 'marriage between Keynesianism and Monetarism, ${ }^{59}$ and new social democratic balance between efficiency and social justice, Owen's 'social market economy' or 'social market' theme was an attempt to define and consolidate the 'need

57 Guardian, 9 March 1977; Manifesto Group, What We Must Do, 19.

58 Hayter, Fightback, 49-73; Crewe and King, SDP, 24, 90.

59 Hayter, Fightback, 55-6. 
to create a new synthesis of ideas' to maintain the 'values and attitudes' of previous centre-left theorists in the new political climate and agenda of the 1980s. ${ }^{60}$ Emerging New Right free market themes and ideas promulgated by Keith Joseph and the Conservative Centre for Policy Studies (CPS) required a response and adaptation in Labour's own political thinking and social democratic evolution. The first draft attempt to merge previously contradictory or ambiguous themes of social democratic political economy was that of the Manifesto Group in a 'cold climate' and largely hostile party environment. Owen's 'social market' represented a more theorized and coherent attempt to apply the new synergies implicit in the concept to the social democratic model from a seemingly loftier or more independent revisionist vantage point. ${ }^{61}$ Owen's prescriptions consistently echoed earlier nascent and cautious Manifesto Group themes around greater economic and industrial efficiency involving a more forward-looking commercial climate and a greater role for markets, control of inflation, and careful review of the structure, culture, and commitments of the public sector. Control of inflation, greater national and international competiveness, 'economic adjustment' for wealth creation, and critique (from the centre-left) of high levels of public expenditure, underpinned by the role and operation of the market, were essential to the revival of the British economy and effective policies of social justice. In his own way, 'Owen was attempting to create a new "third way" for the 1980s,' and his attempt to present a synthesis that adapted to new market economic conditions and maintain a strong, if more prudent, commitment to social justice found favourable comparison with the likes of Roy Hattersley and revisionist social democrats still in the Labour Party. ${ }^{62}$

The further migration of these post-revisionist social democratic ideas and proposals can be identified in their eventual manifestation in the 'renewal' of Labour's ideological and policy platform after the 1987 election defeat and in their further development by the arch modernisers of 'New' Labour. For instance, Neil Kinnock described the 'big idea' behind Labour's 1989 Policy Review as the 'the combination of social justice and economic efficiency', an overarching theme obviously close to Owen's 'social market' of 'economic efficiency through market allocation', and more emphasis on wealth creation

60 See Dean Blackburn, 'Facing the future? David Owen and Social Democracy in the 1980s and beyond', Parliamentary Affairs, 64 (2011), 634-5.

61 See Duncan Brack, 'David Owen and the Social Market Economy', Political Quarterly, 61 (1990), 465; Matthew Lakin, 'David Owen, New Labour and the social market economy: The renewal of Social Democratic politics', Social Market Foundation, (London, 2009) (http://www.smf.co.uk/ assets/files/Dissertation_Lakin.pdf: accessed 1 October 2010).

62 Brack, 'David Owen', 465-8; David Owen, Social Market and Social Justice (London, 1987). 
plus social justice via relative redistribution, and Manifesto Group analysis before it. ${ }^{63}$ The attempts of, first, the Manifesto Group of centre-right Labour MPs and then David Owen to reposition Labour and the SDP respectively on 'less familiar social democratic territory', which involved reappraisal of conventional demand management and public expenditure policies, recognition of enterprise and wealth creation, and the influence and role of the market and private sector as 'necessary recognition that times had changed', also found some resonance among the modernisers of early 'New' Labour. ${ }^{64}$ There are broad thematic similarities in the revisionist social democratic lineage from the Manifesto Group through the Owenite SDP in particular and Labour's post-1987 programmatic 'renewal' to 'New' Labour. Although it remains problematic to identify and measure precise points and influence of intellectual heritage, there is a sense in which various attempts to unearth a new synergy of social democratic ideas and plot a new 'third way' course on unchartered social democratic terrain were more than just 'a by-product of their similar ideological trajectories'. ${ }^{65}$ Their eventually explicit and dominant manifestation and expression in 'New' Labour conceals a longer social democratic revisionist 'third way' trajectory of common substantive roots back to the marginalized, neglected, and pioneering Manifesto Group.

\section{Conclusion}

The Manifesto Group represented a clear attempt at factional organization on the parliamentary Labour right from late 1974. Although generally moderate in its ideas and proposals, attempting to steer an economic course between the extremes of left-wing collectivism and Thatcherite neo-liberalism, and founded initially as a focal point for 'moderate' unity and organization against the Labour left in the PLP, the Manifesto Group was not a parliamentary Labour right faction in the conventional leadership-loyalist sense. It was also eager to display its relative independence from the government and voted against it on a number of occasions between 1974 and 1979, as it considered it important to be seen as a conditional supporter of the government. ${ }^{66}$ The Manifesto Group perceived itself to be only a 'critical friend' of the Labour government. In the context of the acute economic difficulties of the

63 Brack, 'David Owen', 463.

64 Mandelson and Liddle, Blair Revolution, 28-9.

65 See Blackburn, 'Facing the future', 647.

66 John Horam, interview with the author. 
mid-1970s, it urged the government to develop a firmer line on the need to review fundamental aspects of traditional social democratic political economy and the 'old ... social democratic subsumption of labourist economism' in its support for 'a permanent but flexible incomes policy [and] a careful review of public expenditure and anti-inflation measures'. A range of internal Manifesto Group statements on economic policy provided clear support of the government's strategy to reduce inflation in order to create economic stability and foster economic growth and pursue an emerging post-Croslandite revisionist social democratic agenda. They stress the reduction of inflation as the key target of economic policy as the only way towards economic stability, growth, and efficiency, and as the basis of stable employment and increased but efficient public expenditure. ${ }^{67}$

The general direction of Manifesto Group economic policy statements was threefold: first, clear acknowledgement of the limitations of traditional social democratic economic tools and methods in post-OPEC conditions; second, explicit and extensive criticism of the general helpfulness and implicit dangers of left-inspired alternative economic strategies of 'unilateral' import controls or 'a large competitive depreciation of sterling'; third, tentative proposals for cautious 'internationally co-ordinated' growth and reflation. In this respect, immediate priorities would be the control and further reduction of inflation by means of 'continuing restraint in wage bargaining' and the need for some form of institutionalized 'flexible incomes policy' and 'firm monetary control'. ${ }^{68}$ In so far as the group offered positive policy ideas and proposals, it encouraged an increased emphasis in social democratic philosophy and political economy on the control of inflation, clearer guidelines for the control of wage demands and public expenditure, and a new focus on wealth creation as opposed to wealth (re)distribution and wider issues of individual choice and freedom.

This 'new' social democratic thinking not only set core members of the Manifesto Group apart from increasingly centrist 'egalitarian' social democrats such as Crosland and Hattersley, but gives some credence to the idea of, if not a wholesale paradigm shift in economic policy in the direction of neo-liberal monetarism and the fracture of the post-war Keynesian social democratic consensus, then some sort of philosophical sea-change in the basis and purpose of social democratic economic policy. While such ideas

67 LHA, LP/MANIF/3, John Wakefield, 'Public expenditure cuts: The chancellor's remarks and further comments', 12 July 1976; Manifesto Group, 'Keep on course'; Manifesto Group, 'Statement on the budget'; Manifesto Group, Statement, 15 November 1978; David Marquand, John Mackintosh, David Owen, 'Change gear! Towards a socialist strategy', Socialist Commentary, October 1967, iv-v; Desai, Intellectuals and Socialism, 156-7, 172.

68 Manifesto Group, 'Economic policy', 4-5, 9-14. 
still played at the margins of social democratic thought and practice, Labour now appeared more willing to address intrinsic limitations of traditional social democratic political economy in the circumstances of the 1970s, to consider the need to adapt fundamental aspects of economic thinking to the new conditions, and even to reconceptualize the balance of guiding principles in the direction of greater emphasis on individual freedom.

Beyond its internal success against the Tribune Group in the organization of the right-wing 'slate' for PLP elections, some of the constraints and limited impact of the Manifesto Group reflected rifts over the divisive issue of Europe and emerging differences with the wider Labour right tendency of the PLP in the 1970s. For instance, it contained within its (seventy plus) membership a diverse range of broadly centre-right Labour MPs and opinion, including both liberal revisionist Jenkinsites and loyalist centrists hesitant to veer too far away from social democratic orthodoxy. The Manifesto Group struggled to have much wider impact at the time, given the diversity and constraints of its internal organization and the fact that, by this stage, it appeared that both inside and outside the party the tide of ideas was against it. Perhaps lacking coherent membership and a wider intellectual purpose beyond its position as a 'critical friend' of the Labour government and discussion of the 'minutiae of anti-inflation policy - demanding more firmness and consistency', the majority of the Manifesto Group membership was less concerned to develop a wider coherent set of principles, ideas, and proposals, within the context of a comprehensive statement of social democratic intent appropriate to the new conditions, than (perhaps inevitably) with the immediate priority to maintain the Labour government and a moderate democratic socialist programme in office and to stem the left-wing tide in the party.

In the challenging circumstances of 'new and unanticipated [economic] problems', the Manifesto Group focused largely on the need for 'careful review of public expenditure and anti-inflation measures' and the need for a flexible but permanent incomes policy. ${ }^{69}$ Although invitations to speakers and the agendas of Manifesto Group meetings reveal a desire to expand the prospectus of political discussion on occasion (to issues such as devolution), the majority of meetings and all significant internal documentation were devoted to issues of inflation and public expenditure. ${ }^{70}$ The limited

69 Manifesto Group, 'Economic policy', 4-5, 9-14.

70 In addition to its general policy statements, see Marquand, 'Economic situation'; Manifesto Group, 'Keep on course'; Manifesto Group, 'Statement on the budget'; LHA, LP/MANIF/3, Manifesto Group, 'After phase two', June 1977; LP/MANIF/4, Ian Wrigglesworth, Notes of Manifesto Group meeting, 1 December, 1976; Notes of Manifesto Group meeting, 8 December 1976; Sydney Irving, notes on Manifesto Group meeting, 9 February 1977; notes on Manifesto Group 
concerns of the Manifesto Group were perhaps understandable given national priorities and the group's originally limited ambition to support the Labour government in the interests of right-wing unity against the challenge of the new Labour left. Wider aspirations to develop and propose a more inclusive set of ideas and proposals, beyond the odd 'laudable modernising sentiment' and the defensive, moderate 'middle course' between the economic extremes of left and right, was curtailed to some extent by a combination of its defensive position, the priorities and wider conflicts and arguments of the prevailing context and the diversity and tensions of group membership. Nevertheless, core Manifesto Group themes and initiatives, temporarily diverted via alternative social democratic vehicles, reappeared in the early vision and statements of 'New' Labour in the wake of the party's own long revisionist modernizing trajectory.

\section{Notes on contributor}

Stephen Meredith teaches politics and contemporary history in the School of Education and Social Science at the University of Central Lancashire. He researches and has published widely in the areas of Labour Party history and social democratic and wider 'progressive' politics. He is the author of Labours Old and New: The Parliamentary Right of the British Labour Party 1970-79 and the Roots of New Labour (Manchester University Press, 2008) and is an elected Fellow of the Royal Historical Society.

Correspondence to: scmeredith@uclan.ac.uk

meeting, 15 June 1977; George Robertson to Bill Rodgers, Shirley Williams, David Owen, Roy Mason, and Roy Hattersley, 7 July 1980; George Robertson to Manifesto Group Members, 7 July 1980; also see Desai, Intellectuals and Socialism, 171-2. 